\title{
SOCIO-ECONOMIC FACTORS INFLUENCING POVERTY AMONG RURAL HOUSEHOLDS IN ONICHA LOCAL GOVERNMENT AREA, EBONYI STATE, NIGERIA
}

\author{
V.A. Eze ${ }^{1 *}$, N.E. Odoh², O.E. Igwe ${ }^{2}$ and C.J. Mgbanya ${ }^{3}$
}

Received 8 March 2019, Revised 18 May 2019, Accepted 24 June 2019, Published online 30 June 2019

\begin{abstract}
The study examined the socio-economic factors influencing poverty among rural households in Onicha Local Government Area of Ebonyi state, Nigeria. The study adopted multistage random and purposive sampling techniques to select 120 household heads. Primary data used for the study were collected using structured questionnaire. The data were analysed with the aid of means, percentage and frequency count and OLS multiple regression model. The result indicated that the households spent an average of $\$ 31,250$ monthly to take care of their families and other essential personal needs. The result of the socio-economic characteristics showed that majority (53.3) of the respondents were females. The mean age was 36 years with majority (64.2\%) married while an average of 6 persons per household was recorded. The predominant occupations were farming (36.0\%) and civil service (35.8\%). The households cultivated a mean farm size of 3.8 hectares, the mean monthly income was $\$ 19,720$ while their average monthly expenditure amounted to $\$ 31,250$. Moreover, $73.3 \%$ of the respondents belonged to one social organization or the other with over $90.0 \%$ of them having acquired various forms of formal education. The multiple regression result showed the coefficient of determination $\left(\mathrm{R}^{2}\right)$ was 0.644 or $64.4 \%$. The overall model was statistically significant $(\mathrm{P}<0.05)$, signifying that the selected socio-economic characteristics of the households have significant influence on their poverty level. The coefficients of age, sex, educational attainment, household size, farm size, income and membership of social groups were statistically significant. The hypothesis tested led to the conclusion that the selected socio-economic characteristics have significant influence on the poverty level of the households. The study recommended improvement of socio-economic attributes that improve the poverty level of rural households.
\end{abstract}

Keywords: Households, Poverty, Socio-Economic Attributes, Onicha LGA, Ebonyi State

\footnotetext{
${ }^{1}$ Department of Agribusiness and Management \& Trade, Kenyatta University, Kenya.

${ }^{2}$ Department of Agricultural Economics, Management and Extension, Ebonyi State University, Nigeria.

${ }^{3}$ Department of Agribusiness and Management, Michael Okpara University of Agriculture, Umudike, Abia State, Nigeria.

*Corresponding author’s email: ezeanayochukwu09@gmail.com (V.A. Eze)
}

Cite this article as: Eze, V.A., Odoh, N.E., Igwe, O.E. \& Mgbanya, C.J. (2019). Socio-economic factors influencing poverty among rural households in Onicha local government area, Ebonyi State, Nigeria. Int. J. Agril. Res. Innov. Tech. 9(1), 8-13.

\section{Introduction}

Poverty is characterized by lack of income and productive resources, lack of purchasing power, exposure to risk, malnutrition, high mortality rate, low life expectancy, and insufficient access to social and economic services (Adebayo, 2013). In Nigeria, poverty is not a new phenomenon. However, in the last two decades, incidence of poverty has been on the increase despite its physical and human resources. The country has an estimated population of over 190 million people ( 51 percent male, 49 percent female) with an estimated growth rate of 2.43 percent per annum and a high dependency ratio of 88 percent (NBS, 2017).

NBS (2005) reported that poverty in Nigeria is mostly feminized and widespread in the rural areas. In other words, poverty is considered severe in rural areas, where up to 80 percent of the population lives on below the poverty line of US \$1.9 and social service and infrastructure are limited (Olawuyi and Adetunji, 2013). Over 70 percent of Nigerians are still classified as poor, with about 35 percent of them living in absolute poverty (Olawuyi and Adetunji, 2013).

Nigeria's poverty index according to (UNDP, 2016), rose to 53.7 percent. World Bank asserts that individual or person who lives or earn below $\$ 1.9$ per day is considered to be extremely poor. Going by this, the Bank averted that Nigeria has overtaken India, as the country with the highest number of extreme poor individuals (Babalola, 2018). This suggests that about 86.99 million 
people in Nigeria are presently living under extreme poverty line. Certainly, the situation has dire consequences for the socio-economic wellbeing of the citizenry, because it further weakens the nation's ability to improve its income drive. More so, it fosters growing dependency ratio, crime rate and widening inequality, which put the socioeconomic fabric of the country under severe pressure. With the present population dynamic, 45.7 percent of the Nigerian population is considered extremely poor far higher than the sub Saharan average ratio of 30 and worse off than Somalia (Babalola, 2018).

In Ebonyi State, poverty is highly pervasive. The State remains the only State in South East that made the list of ten poorest States in Nigeria. The incidence of poverty in the State is 58.9 percent (Emejo, 2018), this reflects the percentage of Ebonyians who are poor. Poverty appears to be one of the state's deadliest diseases. Poverty in Ebonyi is a pervasive phenomenon characterized by low level of income and social deprivation. According to Chukwu (2012), over 85 percent of the population of Ebonyi state resides in the rural areas, where the economically active workforce is about 38 percent. The income of most rural households is mainly from agricultural and nonagricultural employments, appears to be too merged. The inadequacy of this merge income has compelled several rural agricultural labourers to drift to urban centers in search of greener pasture. However, the rural urban drift has not in any way bettered the economy of rural dwellers in Ebonyi State. Recent observations suggest that most families neither experience income mobility nor a shift in position along their income scale. This phenomenon encourages static socioeconomic status which makes the poor to remain trapped in the vicious cycle of poverty while the rich get richer.

To address this challenge, government has over the years developed various policy interventions programmes for poverty alleviation. These programmes include: National Poverty Eradication Programme (NAPEP), Family Economic Advancement Programme (FEAP), Sustainable Development Goals (SDGs), N-Power and many others Federal and States governments poverty interventions programmes and projects. Despite the various government poverty intervention programmes, the incidence of poverty is still very alarming with more citizens slipping into poverty cycle. Amidst these efforts to reduce poverty, it is still unclear why rural households in Ebonyi State are not taking advantage of these poverty intervention programmes to alleviate poverty. Therefore, there is need to investigate the socio-economic factors influencing poverty among rural households in Onicha LGA, Ebonyi State. Specifically, the study sought to describe the personal characteristic of households, and determine the influence of selected socio-economic/ personal characteristics of the households on their poverty level.

The study further proposed to subject the null hypothesis that the selected socio-economic characteristics of the households have no significant influence on their poverty level in Onicha LGA in Ebonyi State into analysis.

\section{Methodology}

The study was carried out in Onicha Local Government Area (LGA) of Ebonyi State. The LGA is one of the 13 local government areas that make-up Ebonyi State. It is made up of 8 autonomous communities, namely: Onicha Igboeze, Igboeze Onicha, Ukawu, Isuokoma, Abaomage and Oshiri. The local government has a landmass of approximately 559.62 sq. $\mathrm{km}$ and lies between latitude $6.10^{1} \mathrm{~N}$ and longitude $7.46^{1} \mathrm{E}$ and $8.15^{1} \mathrm{~W}$ (Ebonyi State Ministry of Land, Survey and Urban Planning, 2006). It has a population of 117,832 males and 118,777 females making a total of 236,609 (NPC, 2006) out of which of six hundred and forty (640) are Ebonyi State Agricultural Development Programme (EBADEP) contact farmers. Residents of Onicha local government area are Igbo speaking people with farming as their major occupation. The food crops produced in the area include yam, cassava, vegetables, rice, sweet potatoes and cocoyam. The population of study comprised all household heads that are residing in the LGA.

Multistage random and purposive sampling techniques were used to select the respondents for study. The study established predetermined criteria which served as benchmark for selection of the respondents. The criteria include household heads who are resident in the study area, and are carrying out their economic activities within the same locality. The use of household heads as the sample respondents was to ensure that only people who have requisite information needed for this study were selected. Based on the foregoing, the household heads were selected thus: four (4) communities out of the eight autonomous communities in the area were randomly selected. Three villages each were selected randomly from the four communities to get a total of twelve villages. From each of the twelve villages selected, ten households head were purposively selected to reflect the predetermined criteria. Thus, to give a total of hundred and twenty (120) respondents were used for the study.

The data were collected with the aid of structured questionnaire and interview schedule. The statistical tools for data analysis include descriptive statistics such as mean, percentage and frequency count and inferential statistics of multiple linear regression analysis while Fstatistics was used to test the null hypothesis. 


\section{Model specification for multiple regression analysis}

The model for the multiple linear regression is presented as:

$Y=\alpha_{0}+\beta_{1} X_{1}+\beta_{2} X_{2}+\beta_{3} X_{3}+\beta_{4} X_{4}+\beta_{5} X_{5}+\beta_{6} X_{6}$ $+\beta_{7} X_{7}+\beta_{8} X_{8}+U$

Where: $\mathrm{Y}=$ poverty level (poverty index)

$\mathrm{X}_{1}=$ age (years)

$\mathrm{X}_{2}=\operatorname{sex}($ male $=1$, female $=0)$

$\mathrm{X}_{3}=$ marital status (single $=1$, married $=2$, widowed $=3$, separated $=4$ )

$\mathrm{X}_{4}=$ educational level attained (years spent in formal schooling)

$\mathrm{X}_{5}=$ household size (number)

$\mathrm{X}_{6}=$ farm size (ha)

$\mathrm{X}_{7}=$ monthly income (naira)

$\mathrm{X}_{8}=$ membership of social organization (yes $=1$, no $=0$ )

$\alpha_{0}=$ constant

$\beta_{1}-\beta_{8}=$ parameter estimates

$\mathrm{U}=$ Stochastic error term

\section{Results and Discussion}

\section{Socio-economic characteristics of the households}

The socio-economic attributes of the respondents were examined and the result presented in Table 1. The age distribution of the respondents as shows that $47.5 \%$ were between $31-40$ years. The mean age of the respondents was approximately 36 years, which implies that the respondents were mostly middle aged people who are still within their economic active age. The finding slightly differs from that of Ayoade and Adeola (2012) who reported a mean age of 43 years among households in Oyo State. Sex is an important factor in assessing poverty level because it affects individual gender in diverse way. The result indicates that there was more (53.3\%) females' headed household than males (46.7\%). The higher percentage of female headed households in the study area, suggests that these females serve as bread winners to their household members. This could be because of high rate of migration of males to the urban area in search of greener pasture and increasing number of widow in the study area. The finding is contrary to that of Babatunde et al. (2008) who reported that 84 percent of rural households in South western Nigeria are male-headed. The result showed that $90.8 \%$ of the respondents were Christians while 9.2\% of them were traditional worshipers. This signifies that Christianity is the dominant religion of the people in the study area. The result agrees with that of Ayoade and Adeola (2012), who reported that Christianity is prevalent religion in Southern Nigeria. Equally, the result shows that $64.2 \%$ were married. This result indicates that majority of the respondents were married thus they have the responsibility of catering for the family members in order to reduce poverty in the household. With higher percentage of married couple, their level of living is expected to be positively affected as the responsibility of maintaining the household's standard of living will be bored by both couples. Household size is a function of the number of wives and persons staying with the household head. Table 1 showed that $37.5 \%$ had $4-6$ persons in their family. Similarly, Ayoade and Adeola (2012) reported an average of 5 members per household in Oyo State. The result shows that majority of the respondents had 4-6 persons in their houses. This could be because the respondents had learnt about family planning and so did not gave birth too many children. This was in line with the findings of Bullion (2003) who opined that households who adopted family planning gave birth to fewer children than illiterate households who do not adopt family planning. The result also shows that the average farm size per household is 3.8 hectares. Since majority of the respondents cultivate between 3-4 hectares, it implies that the households engaged in farming at small scale level which generally results in low output in agricultural production. In almost all the rural areas in Nigeria, people engage in different economic activities to earn a living. The primary occupation of the respondents shows that most (36.0\%) and (35.8\%) were farmers and civil servant, respectively. This implies that majority of the respondents earn their living from farming activities. This finding conforms to that of Ayoade and Adeola (2012), who reported that the primary occupations of most households in Oyo State were farming, teaching and trading. Furthermore, Omoregbee and Edeogbon (2006) in their study on diversification of livelihood among rural households found that $90.0 \%$ of poor households relied on farming as a major source of income. From the result of the analysis, it was also observed that the respondents had averagely 2 persons with gainful employment in their households, $87.5 \%$ of the respondents had 1-2 persons employed in their households. The mean monthly income of the respondents was $\$ 19,720$. Furthermore the result of the analysis also showed that most $(25.0 \%)$ of the respondent earned below $\$ 5,000$, The result revealed that majority of the household earned within the $\$ 18$,ooo monthly minimum wage approved by the federal government of Nigeria, which is an indication that they are low income earners. This finding agrees with Ayoade and Adeola (2012) who reported an annual income of $\$ 181,290$ among households in Oyo State, Nigeria. Poor income results to households been trapped into the web of poverty. In support of this assertion, Babatunde et al. (2008) opined that there is correlation between income and poverty level, since income is the major determinant of household expenditure. The income of the household is a function of number of persons working in the household and at-times the level of education. The result of the analysis showed that, the households spent an average amount of \$1,250 monthly to take care of their families and other essential personal needs. The table also showed that majority $(81.7 \%)$ of the households spent below 40 ,000 monthly. This is an indication area was low and this could be because of low level of income earned by the respondents. This is confirmed by Olawuyi and Adetunji (2013) finding that poverty is considered severe in rural areas, where up to $80 \%$ of the population lives on 
below the poverty line of US $\$ 1.25$ ( $\$ 400$ ) per person in a household per day.

Table 1. Distribution of the households according to socio-economic characteristics.

\begin{tabular}{|c|c|c|c|}
\hline Socio-economic & Frequency $(n=120)$ & Percentage & Mean \\
\hline \multicolumn{4}{|l|}{ Age (years) } \\
\hline$<21$ & 4 & $3 \cdot 3$ & \\
\hline $21-30$ & 31 & 25.8 & \\
\hline $31-40$ & 57 & $47 \cdot 5$ & 36 \\
\hline $41-50$ & 16 & 13.3 & \\
\hline Above 50 & 12 & 10.0 & \\
\hline \multicolumn{4}{|l|}{ Sex } \\
\hline Male & 56 & 46.7 & \\
\hline Female & 64 & $53 \cdot 3^{*}$ & \\
\hline \multicolumn{4}{|l|}{ Marital status } \\
\hline Single & 28 & $23 \cdot 3$ & \\
\hline Married & 77 & 64.2 & \\
\hline Divorced & 4 & $3 \cdot 3$ & \\
\hline Widowed & 11 & 9.2 & \\
\hline \multicolumn{4}{|l|}{ Religion } \\
\hline Christianity & 109 & 90.8 & \\
\hline Traditional worshipper & 11 & 9.2 & \\
\hline \multicolumn{4}{|c|}{ Educational qualification } \\
\hline No formal education & 44 & 36.7 & \\
\hline Primary & 12 & 10.0 & \\
\hline Secondary & 23 & 19.2 & \\
\hline HND/B.sc & 38 & 31.7 & \\
\hline Higher degree & 3 & 2.5 & \\
\hline \multicolumn{4}{|c|}{ Household size (number) } \\
\hline $1-3$ & 24 & 20.0 & \\
\hline $4-6$ & 45 & $37 \cdot 5$ & 6 \\
\hline $7-9$ & 26 & 21.7 & \\
\hline Above 9 & 25 & 20.8 & \\
\hline \multicolumn{4}{|l|}{ Farm size (hectare) } \\
\hline $1-2$ & 34 & 28.3 & \\
\hline $3-4$ & 52 & $43 \cdot 3$ & 3.8 \\
\hline $5-6$ & 15 & 12.5 & \\
\hline 7 and above & 19 & 15.8 & \\
\hline \multicolumn{4}{|l|}{ Primary occupation } \\
\hline Trading & 21 & 17.5 & \\
\hline Artisan & 12 & 10.0 & \\
\hline civil services & 43 & 35.8 & \\
\hline Farming & 44 & 36.7 & \\
\hline \multicolumn{4}{|l|}{ Monthly income ( } \\
\hline$<5000$ & 30 & 25.0 & \\
\hline $5000-9900$ & 29 & 24.2 & 19720 \\
\hline $10000-19900$ & 12 & 10.0 & \\
\hline 20000-29900 & 11 & 9.2 & \\
\hline $30000-39900$ & 23 & 19.2 & \\
\hline $40000-49900$ & 8 & 6.7 & \\
\hline 50000 and above & 7 & 5.8 & \\
\hline \multicolumn{4}{|c|}{ Monthly consumption ( $\mathbb{N}$ ) } \\
\hline below 40000 & 98 & 81.7 & 31250 \\
\hline $40000-70000$ & 19 & 15.8 & \\
\hline 70 and above & 3 & 2.5 & \\
\hline \multicolumn{4}{|l|}{$\begin{array}{l}\text { Membership of social } \\
\text { organization }\end{array}$} \\
\hline Yes & 88 & $73 \cdot 3$ & \\
\hline No & 32 & 26.7 & \\
\hline \multicolumn{4}{|l|}{$\begin{array}{l}\text { Household members } \\
\text { employed (Number) }\end{array}$} \\
\hline $1-2$ & 105 & 87.5 & \\
\hline $3-4$ & 12 & 10.0 & 2 \\
\hline $5-6$ & 3 & 2.5 & \\
\hline
\end{tabular}


The table 1 showed that majority (73.3\%) respondents belonged to one social organization or the other with the notion that membership to social group helps its members in times need, thereby acting as a means to coping with poverty. Although, study has shown that there is a high prevalence of poverty among older household heads and those that are non-member of any social group in their community (Adekoya, 2014). The result equally showed that $36.7 \%$ of the respondents had no formal education while $31.7 \%$ had HND/B.Sc degrees. This suggests that some of the respondents could read and write which is essential for accessing poverty alleviation programmes. Education equips the people with information and new technologies that are necessary for enhancing economic activities (Oniang'o and Makudi, 2002). Policy that would ensure sustained and improved access to education will go a long way to reduce poverty in the study area. The role of capacity building and human capital development in eradicating poverty cannot be over emphasis. It has been established that access to education has significant impact on human capital development (Akerele and Adewuyi, 2011), in the forms of improve labour productivity and wages which in turn results in reduction of poverty among households.

\section{Influence of selected socio-economic characteristics of the households on their poverty level}

The result of the regression analysis as presented in Table 2 showed that the multiple regression coefficient (R) was 0.802 or $80.2 \%$, which is an indication that the included independent variables (selected socio-economic attributes) were highly correlated with the poverty level of the households. The coefficient of determination $\left(R^{2}\right)$ was 0.644 or $64.4 \%$, suggesting that $64.4 \%$ of the total variation observed in the poverty level of the households was sufficiently explained by the joint influence of the independent variables included in the regression model. The fitness of the model was further confirmed by the low value of the standard error of the estimate (Std. error $=$ 0.95384 ) and the high value of F-ratio (25.051). The overall model was statistically significant $(\mathrm{P}<0.05)$, implying that the selected socioeconomic characteristics of the households have significant influence on the poverty level of the households in the study area. The coefficient of age was positively signed and statistically significant at $1 \%$. This implies that advance in age will result in increase in the poverty level of the households. People in their old age tend to refrain from most active economic activities because of health and other aging challenges. The coefficient of educational qualification showed negative sign as well as statistically significant at $1 \%$. This implies that acquisition of more education will decrease the poverty level of the households. This conforms to the a priori expectation. The coefficient of farm size was negatively sign and statistically significant at $5 \%$. This implies that a unit increase in farm size will reduce poverty level. Expanding farm size is therefore a means of enhancing income generation and this will positively reflect in the poverty level of the households. Monthly income has negative coefficient and statistically significant at $5 \%$. This means that any unit increase in the monthly income of the households will lead to decrease poverty level. More so, the significant level is an indication that income exerts significant influence on poverty status of the households. Membership of social group has negative coefficient and statistically significant at $1 \%$. This implies that households who are members of social organization can better reduce poverty level of their households. Membership of social organization provides platform for exchange of ideas, knowledge and skills, which can improve one's socio-economic status. Moreover, the significant level shows that membership of social organization exerts.

The coefficient of sex $\left(\mathrm{X}_{2}\right)$ was negatively signed but statistically significant at $5 \%$. This is an indication that household's sex affects their poverty level. The position of male as the households head put them in a position to make virtually decisions that bind on all household's members. The significant level implies that sex is an important determinant of poverty level of the households.

The coefficient of household size showed positive sign and statistically significant at $1 \%$. This means that increasing household size of the respondents will perpetuate poverty level of the households. Large household size will require additional income to meet basic family needs, which in most cases are unattainable. In other words, households with large family size will spend greater portion of their income on feeding, medication, clothing among other necessities. This could push them further downward the poverty level ladder.

The test hypothesis shows that F-cal (25.10) > Ftab (2.62), consequently, the null hypothesis was rejected and the alternative accepted that the selected socio-economic characteristics have significant influence on the poverty level of the households in the study area. 
Table 2. Result of multiple regression analysis of the influence of selected socio-economic characteristics on the poverty level of the households.

\begin{tabular}{|l|l|l|l|}
\hline Variables & Coefficients & Std Error & t-value \\
\hline Constant & 3.529 & 0.797 & $4.430^{*}$ \\
\hline Age & 0.814 & 0.133 & $6.129^{*}$ \\
\hline Sex & -0.517 & 0.200 & $-2.590^{* *}$ \\
\hline Marital status & -0.075 & 0.159 & $-0.473^{\text {NS }}$ \\
\hline Educational attainment & 0.351 & 0.089 & $4^{*}$ \\
\hline Households size & 0.163 & 0.103 & $1^{*}$ \\
\hline Farm size & -0.161 & 0.109 & $-1.473^{* *}$ \\
\hline Monthly income & -0.059 & 0.056 & $-1.062^{* *}$ \\
\hline Membership of social group & -1.120 & 0.234 & $-4.780^{*}$ \\
\hline R & 0.802 & & \\
\hline R & 0.644 & & \\
\hline Adj R & 0.618 & & \\
\hline Std error of estimate & 0.95384 & & \\
\hline F-statistic & 25.051 & & \\
\hline
\end{tabular}

\section{Conclusion and Recommendation}

The study established that the selected socioeconomic characteristics have significant influence on the poverty level of the households in the study area. Consequently, the study identified the socio-economic variables influencing poverty among the households to include: age, sex, educational qualification, household size, farm size, income and membership of social group. It was recommended that government should initiates educational programme for improving the socio-economic attributes of the households as a way of enhancing poverty level of the households. Such programme could include adult educational programme that will improve knowledge and skills of households, which will enable them to take advantage of livelihood opportunities within and outside their immediate environment to improve their standard of living.

\section{References}

Adebayo, O.O. 2013. Analysis of poverty level among urban households in Irewole Local Government Area of Osun State. Global $J$. Arts Human. Soc. Sci. 1(1): 13-19.

Adekoya, O.A. 2014. Analysis of farm households poverty status in Ogun States, Nigeria. Asian Econ. Finan. Rev. 4(3): 325-340.

Akerele, D. and Adewuyi, S.A. 2011. Analysis of Poverty Profiles and Socioeconomic Determinants of Welfare among Urban Households of Ekiti State, Nigeria. Curr. Res. J.Soc. Sci. 3(1): 1-7.

Ayoade, A.R. and Adeola, R.G. 2012. Effects of Poverty on Rural Household Welfare in Oyo State, Nigeria. Global J. Sci. Front. Res. 12(4): 44-52.

Babalola, T. 2018. Poverty Tracker: Raising the Red Flag. Proshare Confidential. 1(181): 1600 - 8842. www.proshareng.com.

Babatunde, R.O., Olorunsanya, E.O. and Adejola, A.D. 2008. Assessment of Rural Household Poverty: Evidence from South-western Nigeria. American-Eurasian J. Agric. Env. Sci. 3(6): 900-905.
Bullion, A.T. 2003. An appraisal of federal government's national poverty eradication programme (NAPEP). CBN Research Department. 5p.

Chukwu, E.O. 2012. Estimates of rural poverty level and income distribution in Ebonyi state of Nigeria. Nigerian J. Agric. Food Env. 8(3): 52-61.

Ebonyi State Ministry of Land, Survey and Urban Planning. 2006. Annual publication. Abakaliki: Ebonyi State Government House.

Emejo, J. 2018. Nigeria's Poverty Index Stands at $53.7 \%$, Says UNDP. Thisday. Retrieved from https://www.thisdaylive.com/index.php/20 18/10/09/nigerias-poverty-index-stands-at53-7-says-undp/

NBS. 2005. Poverty profile for Nigeria. Abuja: National Bureau of Statistics, NBS Publication. pp. 5-8.

NBS. 2017. Nigeria Poverty Profile 2016 Report. National Bureau of Statistics. pp. 3-6. Retrieved from: http://www.tucrivers.org/tucpublications/N igeria\%20Poverty\%20Profile\%202010.pdf.

NPC. 2006. National Population Census Report. Abuja: NPC. p. 18.

Olawuyi, S.O. and Adetunji, M.O. 2013. Assessment of rural household poverty. $J$. Sci. Res. Rep. 2(1): 36.

Omoregbe, F.E. and Edeogbon, C.O. 2006. Diversification of Livelihood among Rural Households in Owan-West Local Government Area, Edo State. Global J. Soc. Sci. 5(1): 25-33.

Oniang'o, R. and Makudi, E. 2002. Nutrition and Gender: A Foundation for Development. Brief 7 of 12, UNACC/SCN, Geneva. Available at: http://ww w.ifpri.org/publications.

UNDP. 2016. An assessment of the status of human security and human development in Nigeria. National Human Development Report 2016. United Nation Development Programme. pp. 32-36. Retrieved from http://www.ng.undp.org/content/nigeria/e n/home/library/poverty/national-humandevelopment-report-2016.html. 